\title{
RELEVANSI PENERAPAN 'IDDAH DI ERA TEKNOLOGI MODERN
}

\author{
Nurnazli \\ Dosen Fakultas Syari'ah UIN Raden Intan Lampung \\ email: nurnazli@,radenintan.ic.id
}

Diterima: 21 November 2016. Disetujui: 03 April 2017

Dipublikasikan: Mei 2017

\begin{abstract}
The development of science and technology today is not a reason to remove the provisions about 'iddah that has been set in the Qur'an and Sunnah. 'Illat law and the purpose of enactment of 'iddah which has been discussed needs to be reviewed. iddah not only to know the empty uterus of the fetus, self-introspection, condition and period of mourning, but there is a higher purpose, that is belief in Allah and honor the noble covenant at the marriage ceremony. The noble agreement is realized in the ijâb and qabûl between men and women guardians. Consequently, if the marriage breaks up either because of death or divorce, both sides must respect the agreement. They must be equally restricted with the iddah way until the time set by Syar'i, especially for women whose existence is more glorified and also the aim of the law' 'iddah is for the common good.
\end{abstract}

Keywords: Iddah, Teknologi Modern dan Perceraian

\section{A. Pendahuluan}

Pembahasan seputar iddah bagi perempuan yang cerai hidup maupun cerai mati bukanlah persoalan yang baru. Banyak kajian-kajian yang telah dilakukan oleh kalangan 
akademisi dengan berbagai pendekatan dan sudut pandang. Mengapa diera teknologi yang semakin canggih ini penerapan iddah masih diberlakukan, dan mengapa hanya perempuan saja yang diwajibkan untuk beriddah.Melalui penelitian ini akan dikaji apa dan bagaimana relevansi penerapan iddah di era teknologi modern. Masih relevankan alasan-alasan diberlakukannya 'iddah yang dikemukakan oleh para pemikir terdahulu.

Pemberlakuan 'iddah sudah ada jauh sebelum Islam datang, meskipun praktiknya tentu jauh berbeda. Tatkala Islam datang, tradisi ini masih tetap dipertahankan dengan berbagai perbaikan dengan tujuan untuk kemaslahatan. Penerapan iddah pada zaman Nabi SAW tidak terlepas dari pengaruh sosio-kultural masyarakat Arab pada waktu itu. Kondisi sosio-kultural pada saat diturunkannya ketentuan dan aturan tentang 'iddah juga tidak terlepas dari latar belakang kehidupan bangsa Arab pra-Islam yang sangat tidak mengakui keberadaan perempuan, bahkan perempuan hanya dipandang sebagai pelengkap. Di sisi lain, dalam konteks budaya patriarkhi kedudukan perempuan dipandang lebih rendah dibandingkan dengan laki-laki. ${ }^{1}$ Karenanya keberpihakan secara naratif al-Qur'an lebih ditujukan kepada kaum laki-laki (khususnya terkait dengan aturan 'iddab ini).

Namun demikian, iddah merupakan ketentuan hukum yang harus diimani dan dilaksanakan oleh para mukallaf tanpa perlu mempertanyakan apalagi menggugatnya, dan merupakan perwujudan ketaatan hamba kepada Allah Swt. Yang perlu untuk ditafsirkan kembali adalah tujuan dan hikmah tasyri' yang terkandung dalam pemberlakuan 'iddah bagi perempuan, baik karena cerai hidup maupun cerai mati.

Kalau tujuan iddah hanya untuk mengetahui kebersihan rahim, seyogyanya dengan satu kali haid sudah menunjukkan perempuan itu tidak hamil. Mengapa 
perempuan yang dicerai harus menunggu tiga kali suci, dan tiga bulan bagi yang belum haid atau monophouse, dan empat bulan sepuluh hari bagi perempuan yang ditinggal mati suaminya.

Perkembangan ilmu pengetahuan dan teknologi modern tidak dapat mengubah ketentuan panjang-pendeknya iddah, terutama dalam kasus-kasus yang sudah jelas dikemukakan al-Qur'an dan al-Sunnah. Sekalipun diyakini dengan ilmu pengetahuan dan teknologi bahwa rahim isteri bersih dan di antara mereka (suami-istri) tidak mungkin rujuk kembali, namun tidak dibenarkan bagi wanita melanggar ketentuan 'iddah yang sudah ditetapkan syara'.

Adapun jenis penelitian ini adalah penelitian pustaka dengan menggunakan pendekatan normatif-tekstual. Pendekatan normatif yaitu model pendekatan dengan melihat ketentuan-ketentuan yang bersumber dari hukum Islam dan pendapat-pendapat ulama mazhab yang tertuang dalam kitabkitab fiqh. Pendekatan tekstual merupakan pendekatan terhadap masalah yang menitikberatkan pada teks dalil-dalil sebagai landasan hukum. Data yang digunakan adalah dalam bentuk data yang sudah didokumentasikan yang disebut dengan bahan hukum primer, yang diperoleh melalui studi pustaka. Kemudian dianalisis dengan menggunakan metode deskriptif kualitatif.

\section{B. Pembahasan}

\section{Konstruksi dan Dasar Hukum 'iddah}

Menurut bahasa iddah berasal dari kata "adad (bilangan dan perhitungan), atau seorang wanita yang menghitung dan menjumlah hari dan masa haid atau masa suci, misalnya bilangan harta atau hari jika dihitung satu persatu dan jumlah keseluruhan. ${ }^{2}$ Pendapat lain menyebutkan

\footnotetext{
${ }^{2}$ Amir Syarifuddin,Hukum Perkawinan Islam di Indonesia, Antara Figh Munaahat dan Undang-Undang Perkasinan, (Jakarta : Kencana, 2007), h. 302
} 
'iddah adalah bahasa arab yang berasal dari akar kata addaya'uddu-iddatan dan jamaknya adalah 'idad yang secara arti kata (etimologi) berarti: "menghitung" dan "hitungan". Kata ini digunakan untuk maksud "iddah karena dalam masa itu si perempuan yang beriddah menunggu berlalunya waktu. ${ }^{3}$

Syaikh Kami Muhammad Uwaidah, ${ }^{4}$ mengkategorikan perempuan yang beriddah (al Mu'taddah) menjadi dua macam kategori, yaitu : Pertama, perempuan yang ber'iddah karena ditinggal mati oleh suaminya. Ketentuan masa iddahnya adalah empat bulan sepuluh hari, dengan catatan tidak hamil, baik pernah dukhul atau tidak. Kedua, perempuan yang beriddah bukan karena ditinggal mati suaminya. Ketentuanmasa iddabnya adalah : sampai melahirkan jika kehamilannya dinisbatkan kepada shahib al 'iddah, atau tiga kali suci jika ia pernah menstruasi, atau tiga bulan, jika belum menstruasi atau sudah putus dari periode haidh (ya'isah).

Abu Yahya Zakariya al-Anshari, memberikan definisi 'iddah sebagai masa tunggu seorang perempuan untuk mengetahui kebersihan rahim, untuk beribadah, atau untuk berkabung (tafajju') atas kematian suaminya. 5 Jadi, 'iddah merupakan masa tunggu yang harus dilalui oleh seorang perempuan disebabkan karena perceraian atau kematian suami, yang mana ketentuan hukum Islam mengharuskan perempuan pada masa iddah untuk menahan diri agar tidak menikah dalam waktu tersebut. Dengan kata lain, iddah hukumnya wajib bagi setiap perempuan yang cerai mati maupun cerai hidup. Kecuali yang cerai qabla al mass.

Lamanya 'iddah tidak sama pada setiap perempuan. Kewajiban ini dijelaskan oleh Allah SWT dalam al-Qur'an surat al-Baqarah ayat 227 sampai 228, sebagai berikut :

${ }^{3}$ Ibid, h. 303.

${ }^{4}$ Syaikh Muhamad Kamil Uwaidah, Al-Jami' fi Fiqh An-Nisa' (Fiqh Wanita : Penerjemah M. Abdul Ghofar, E.M), (Jakarta : Pustaka al-Kautsar, cet. I, 1998), h. 449-450

${ }^{5}$ Abu Yahya Zakariyya al-Ansari, Fath al-Wahhab bi-Syarb Minhaj atTullab, (Semarang: Toha Putra, tt), Juz III, h. 96 


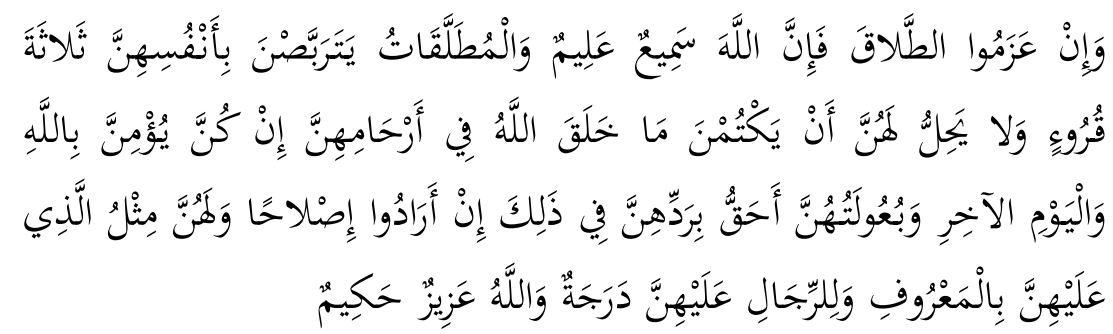

Artinya :

"Dan jika mereka ber'azam (bertetap hati untuk) talak, Maka Sesungguhnya Allah Maha mendengar lagi Maha mengetahui. Wanita-wanita yang ditalak handaklah menahan diri (menunggu) tiga kali quru'. tidak boleh mereka Menyembunyikan apa yang diciptakan Allah dalam rahimnya, jika mereka beriman kepada Allah dan hari akhirat. dan suami-suaminya berhak merujukinya dalam masa menanti itu, jika mereka (para suami) menghendaki ishlah. dan Para wanita mempunyai hak yang seimbang dengan kewajibannya menurut cara yang ma'ruf. akan tetapi Para suami, mempunyai satu tingkatan kelebihan daripada isterinya. Dan Allah Maha Perkasa lagi Maha Bijaksana."

Jika perempuan tersebut hamil, maka masa iddahnya sampai melahirkan. Hal ini sebagaimana disebutkan dalam surah al-Thalaq ayat 4 .

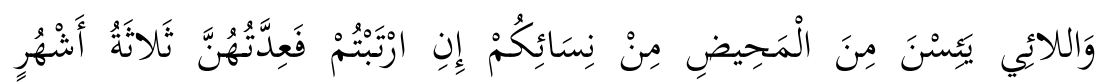

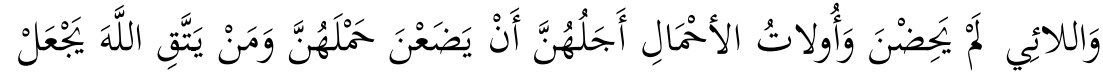
لَهُ مِنْ أَمْهِه يُسْرًا

Artinya:

"Dan perempuan-perempuan yang tidak haid lagi (monopause) di antara perempuan-perempuanmu jika kamu ragu-ragu (tentang masa 'iddahnya), Maka masa iddah mereka adalah tiga bulan; dan begitu (pula) perempuan-perempuan yang tidak haid. dan perempuan-perempuan yang hamil, waktu iddah mereka itu ialah sampai mereka melahirkan 
kandungannya. dan barang -siapa yang bertakwa kepada Allah, niscaya Allah menjadikan baginya kemudahan dalam urusannya."

Al-Qur'an maupun Hadits sangat rinci dan jelas memberlakukan ketentuan 'iddah bagi perempuan, yakni sejak terjadinya perceraian maupun kematian suami, maka iddah mulai diberlakukan hingga waktu yang telah ditetapkan dalam sumber hukum Islam, dengan berbagai konskuensi yang harus ditanggung, baik secara material, biologis, sampai psikologis. Sebagaimana yang tertera di dalam al-Qur'an Suratal-Baqarah ayat 234:

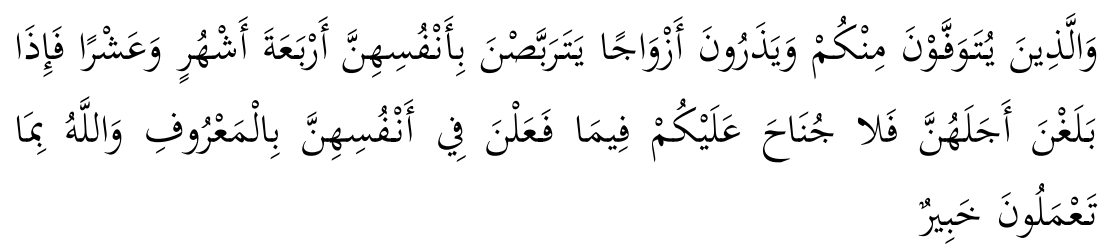

Artinya :

"Orang-orang yang meninggal dunia di antaramu dengan meninggalkan isteri-isteri (hendaklah Para isteri itu) menangguhkan dirinya (ber'iddah) empat bulan sepuluh hari. kemudian apabila telah habis 'iddabnya, Maka tiada dosa bagimu (para wali) membiarkan mereka berbuat terhadap diri mereka menurut yang patut. Allah mengetahui apa yang kamu perbuat."

Tetapi jika tidak hamil, maka masa iddahnya empat bulan sepuluh hari. Hal ini sebagaimana disebutkan firman Allah pada surah Al-Baqarah ayat 234 sebagaimana tersebut.

Penentuan iddah bagi perempuan yang putus perkawinan karena cerai hidup ditetapkan sebagai berikut:

Pertama, iddah bagi wanita yang bercerai dalam keadaan hamil maka masa iddabnya adalah sampai ia melahirkan bayi yang dikandungnya. Kedua, iddah bagi wanita yang telah menstruasi adalah tiga kali suci. Sebagaimana 
disebutkan dalam firman Allah pada surah Al-Baqarah ayat 228.

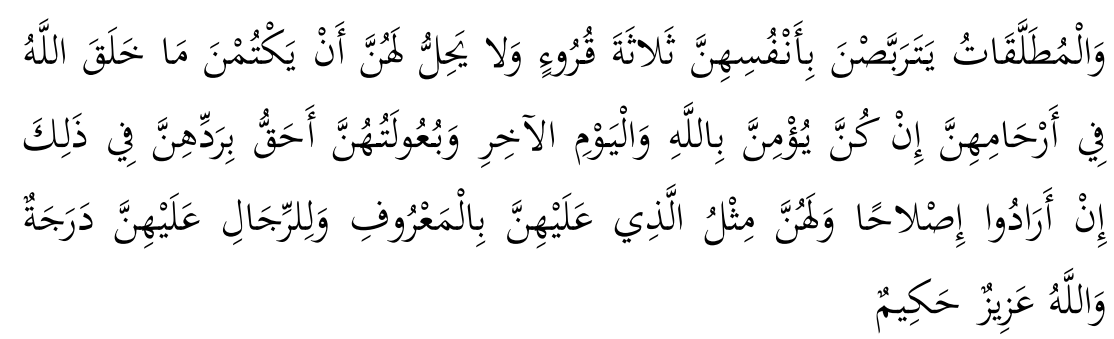

Aprtinya:

"Wanita-wanita yang ditalak handaklah menahan diri (menunggu) tiga kali quru'. tidak boleh mereka Menyembunyikan apa yang diciptakan Allah dalam rahimnya, jika mereka beriman kepada Allah dan hari akhirat. dan suami-suaminya berhak merujukinya dalam masa menanti itu, jika mereka (para suami) menghendaki ishlah. dan Para wanita mempunyai hak yang seimbang dengan kewajibannya menurut cara yang ma'ruf. akan tetapi Para suami, mempunyai satu tingkatan kelebihan daripada isteri. dan Allah Maha Perkasa lagi Maha Bijaksana.

Ayat ini menjpelaskan bahwa seorang isteri yang ditalak harus menjalani 'iddah dengan tiga kali suci. Quru' dapat diartikan suci atau haidh.Suami dapat merujuk kembali isterinya selagi masa iddah isteri belum habis. Hal ini disebabkan karena suami bertanggung jawab terhadap keselamatan dan Kesejahteraan rumah tangga.

Ketiga, dalam keadaan belum dewasa (belum pernah menstruasi) atau sudah putus menstruasi (menopause), 'iddabnya adalah tiga bulan. Keempat, tidak ada iddah bagi perempuan yang belum digauli. Ketika terjadi perceraian atau cerai mati maka ia dapat melangsungkan perkawinan dengan orang lain. Al-Qur'an surat al-Ahzab ayat 49 menjelaskan: 


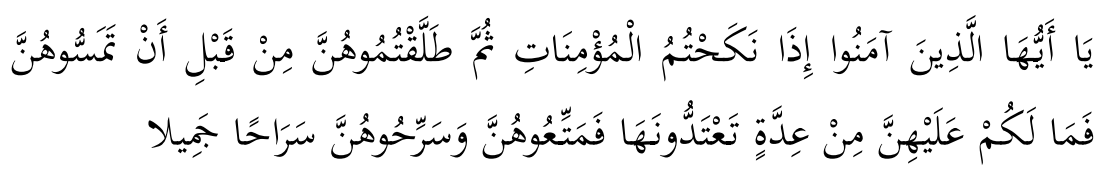

Artinya :

"Hai orang-orang yang beriman, apabila kamu menikahi perempuan-perempuan yang beriman, kemudian kamu ceraikan mereka sebelum kamu mencampurinya Maka sekalisekali tidak wajib atas mereka iddah bagimu yang kamu minta menyempurnakannya. Maka berilah mereka mut'ah dan lepaskanlah mereka itu dengan cara yang sebaik- baiknya."

Tinjauan pertama yang dituntutkan dala paradigma alQur'an adalah apakahh isteri itu sudah digauli (madkbul biha) atau belum (ghair madkbul biba). Ungkapan al-mass (al-tamassu) dalam ayat di atas dipahami oleh para ulama dengan makna al dukbul. ${ }^{6}$ Nampaknya para ulama juga sepakat menyatakan bahwa ungkapan qabla al-tamassubunna berarti qabla al dukbul, sehingga ayat ini dipahami sebagai petunjuk bahwa wanita ghair al madkhul biba tidak perlu menghitung masa 'iddabnya. ${ }^{7}$ Dengan demikian wanita itu diperbolehkan melakukan akan nikah dengan laki-laki lain setelah terjadi perceraian. Berarti persoalan 'iddah dengan segala bentuknya dikaitkan dengan al madkbul biha.

Adapun iddah istri yang hamil itu adalah hingga ia melahirkan. Ketentuan ini didukung oleh turunnya surat atTalaq yang lebih akhir daripada surat al-Baqarah, serta beberapa hadits yang menerangkan bahwa Subai'ah alAslamiyah melahirkan kandungan setelah empat bulan sepuluh hari setelah wafat suaminya, lalu ia memohon izin kepada Rasulullah SAW untuk kawin, kemudian beliau mengizinkannya. Sudah barang tentu meski diperbolehkan mengadakan akad nikah (perkawinan) dalam nifasnya namun

${ }^{6}$ Ibnu Rusyd, Bidayah al-Mujtabid.., h. 66.

${ }^{7}$ Ibid. 
suami tidak boleh mencampurinya sampai ia suci dari nifasnya itu. ${ }^{8}$ Adapun hadits yang menerangkan hal tersebut, adalah :

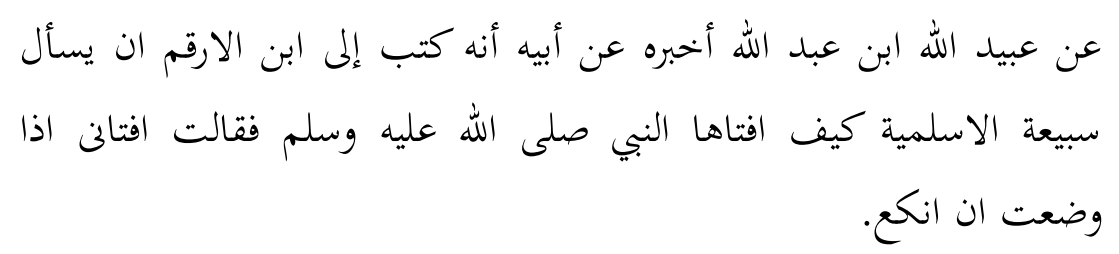

Artinya :

"Dari Ubaidillah bin Abdullah dari ayahnya bahwa ia menulis surat kepada Ibnu Arqam menanyakan kepada Subai'ah alAslamiyah bagaimana Nabi SAW memberi fatwa kepadaku bila saya sudah melahirkan supaya saya kawin."

Selain itu, perempuan yang ditalak raj'i oleh suaminya selama masa 'iddah harus tetap berada di rumah suaminya, tidak boleh keluar tanpa izin dari suami tersebut. Menurut Ibnu Abbas, apabila ia melakukan perbuatan keji secara terang-terangan berperilaku yang tidak baik bagi keluarga suaminya, aka dibolehkan bagi suami untuk mengusirnya. $\mathrm{Hal}$ ini telah ditegaskan dalam al-Qur'an Surat al-Thalaq ayat 1 :

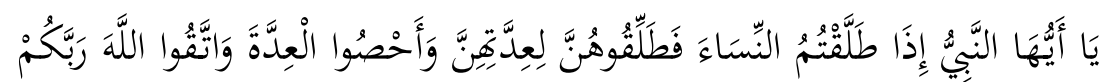

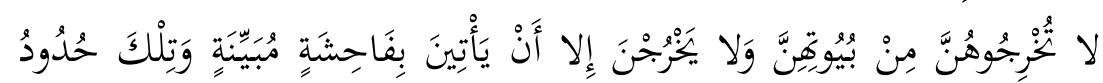

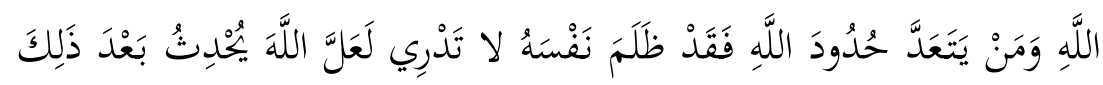

Artinya :

"Hai Nabi, apabila kamu menceraikan istri-istrimu maka hendaklah kamu ceraikan mereka pada waktu mereka dapat (menghadapi) idahnya (yang wajar) dan hitunglah waktu idah

${ }^{8}$ http:/ / www.perkuliahan.com, diakses tanggal 7 Agustus 2017

${ }^{9}$ Imam Abdullah Muhammad bin Ismail al-Bukhari, Sabih Bukhari, jilid VII, terj. Ahmad Sunarto dkk., (Semarang: CV. Asy-Syifa', 1993), h. 224-225.

Pogram Pascasarjana UIN Raden Intan Lampung 


\section{0 ljtimaiyya: Jurnal Pengembangan Masyarakat Islam 10 (1) (2017)}

itu serta bertakwalah kepada Allah Tuhanmu. Janganlah kamu keluarkan mereka dari rumah mereka dan janganlah mereka (diizinkan) ke luar kecuali kalau mereka mengerjakan perbuatan keji yang terang. Itulah hukum-hukum Allah dan barang siapa yang melanggar hukum-hukum Allah, maka sesungguhnya dia telah berbuat lalim terhadap dirinya sendiri. Kamu tidak mengetahui barangkali Allah mengadakan sesudah itu suatu hal yang baru."

Terkait ayat di atas, menurut Imam al-Syaukani, karena predikat isteri belum hilang sehingga masih menyisakan sebagian status dari sisi wanita dan status dari sisi suami. Status itu akan sempurna kembali bila saling rujuk. Apabila wanita tersebut berada dalamstatus tidak diceraikan maka tidak boleh keluar kecuali dengan izin suaminya, karena terkadang suami membutuhkannya sementara ia masih berada di luar rumah yang dapat menimbulkan kecemburuan suami terhadap isteri. ${ }^{10}$

Selanjutnya Ibnu Katsir rahimahullah menafsirkan, sebagai berikut :

$$
\begin{aligned}
& \text { أي: إنما أبقينا المطلقة في منزل الزوج في مدة العدة، لعل الزوج يندم على } \\
& \text { طلاقها ويخلق الله في قلبه رجعتها، فيكون ذلك أيسر وأسهل } 11
\end{aligned}
$$

Artinya :

"Isteri yang dicerai tetap diperintahkan untuk tinggal dirumah suami selama masa iddahnya.Karena bisa jadi suami itu menyesali talak pada isterinya. Lalu Allah membuat hatinya untuk kembali rujuk. Jadilah hal itu mudah.

Menurut kesepakatan fuqaha, perempuan yang sedang menjalani masa 'iddah pada thalaq raj'i berhak mendapat nafkah seperti sebelum perceraian, baik hamil maupun tidak. Dan berhak juga mendapatkan tempat tinggal. Sebagaimana

\footnotetext{
${ }^{10}$ https:/ / almahaj.or.id, di akses tanggal 26 Januari 2018.

${ }^{11}$ Ibnu Katsir, Tafsir Ibnu Katsir, Cetakan III, Darut Thayibah, Maktabah Syamilah $8 / 144$
} 
yang diriwayatkan oleh Ahmad, bahwa Rasulullah SAW bersabda: Sesungguhnya nafkah dan tempat tinggal itu diperuntukkan bagi perempuan yang diwajibkan atas suami bilamana suami masih bisa rujuk kepadanya, maka apabila suami sudah tidak bisa rujuk kepadanya, tidak ada nafkah dan tidak ada tempat tinggal". ${ }^{12}$

Selain ketentuan 'iddah, perempuan yang ditinggal mati oleh suaminya juga disyari'atkan untuk ihdad. Menurut Imam Taqiyyuddin bin Abi Bakar, ${ }^{13}$ menyebutkan sebagai berikut: Dalam ihdad seseorang disyari'atkan terhadap perempuan yang ditinggal mati suaminya, adalah karena sebagai konsekuensi logis terhadap ikatan suami isteri, yang telah dengan sengaja dibentuk dan untuk beribadah dalam rangka melaksanakan legislasi hukum yang ditetapkan oleh Allah dengan demikian, karena ikatan suami isteri adalah sangat suci, maka tidak sah secara syara', merusak janji tersebut dengan melakukan hal-hal yang menimbulkan fitnah dan seorang perempuan ditinggal mati suaminya yang kemudian berlebihan dalam berdandan dan mengenakan pakaian mewah, sekaligus memakai wangi-wangian, adalah menujukkan sikap tidak baik, karena selain tidak mengikuti ketentuan syari'at.

\section{Tujuan dan Hikmah 'iddah Menurut Para Ulama}

Pemberlakuan iddah terhadap seorang perempuan merupakan ketentuan hukum baku yang ditetapkan oleh alQur'an. Hanya saja hikmah yang terkandung dalam penerapannya tidak dijelaskan. Oleh sebab itu para pemikir/fuqaha seperti Imam-Imam Mazhab banyak melakukan kajian-kajian terhadap pemberlakuan iddah tersebut. Ini merupakan upaya untuk merasionalkan hukum baku yang telah ditetapkan oleh musyarri. Para ulama

${ }^{12} \mathrm{HR}$. Ahmad.

${ }^{13}$ Imam Taiqyy Al-din Abi bakar, Kifayah al-Akhyar, (Beirut, Lebanon: Dar al-Kutub al-Ilmiyyah, 2005), h. 567-568 


\section{2 ljtimaiyya: Jurnal Pengembangan Masyarakat Islam 10 (1) (2017)}

melakukan berbagai menafsiran tentang tujuan dan hikmah 'iddah tersebut dengan berbagai argumentasi. Penafsiran para ulama tersebut disesuaikan dengan situasi dan kondisi yang ada pada masanya. Juga tidak terlepas dari sistem kekerabatan patrilineal yang cenderung dianut pada masyarakat waktu itu.

Tujuan iddah menurut Abi Yahya al Zakariya adalah untuk mengetahui kebersihan rahim seorang perempuan, untuk melaksanakan ibadah, dan untuk menghilangkan rasa duka bagi seorang perempuan yang kematian suaminya.

Setelah dilakukan penelusuran pada literatur-literatur seperti Fiqh al-Sunnah, I'anatu al-Thalibin dan Kitab al-Fiqh ala al Mazhahibu al-Alrba'ah, para ulama merumuskan sekurangkurangnya terdapat lima hikmah yang terkandung di dalam ketentuan 'iddah bagi perempuan, baik karena cerai hidup maupun karena cerai mati, hikmah tersebut meliputi :

a. Untuk mengetahui kebersihan rahim seorang perempuan/isteri;

b. Untuk memberikan kesempatan kepada keduabelah pihak suami dan isteri yang bercerai hidup guna merajut kembali ikatan perkawinan yang kandas dan putus karena perceraian, sehingga diberikan peluang untuk mengoreksi kelemahan dan kekurangan masing-masing.

c. Untuk menjunjung tinggi nilai-nilai yang terkandung dalam sebuah perkawinan, yaitu dengan menghimpun orang-orang arif mengkaji masalahnya, dan member tempo berfikir pada kedua belah pihak. Jika tidak demikian, maka tidak ubahnya seperti anak-anak.

d. Keagungan perkawinan tidak terwujud sebelum suami isteri hidup lama dalam bingkai rumah tangga. Jika terjadi sesuatu yang mengharusan putusnya perkawinan, maka untuk mewujudkan tetap terjaganya kelanggengah harus diberi tempa memikirkan dan memperhatikan kerugiannya.

e. Semata-mata ibadah kepada Allah dan mematuhi perintahnya yang terkandung di dalam al-Qur'an, 
dimana perintah itu diperuntukkanbagi perempuanperempuan muslimah.

Hikmah diberlakukannya iddah pada prinsipnya tidak hanya ditujukan untuk kaum perempuan saja, tetapi juga adanya 'iddah membawa kemaslahatan bagi laki-laki (suami), karena Islam menurunkan aturan iddab adalah untuk kemaslahatan bagi semua pihak, baik suami, isteri maupun keluarga keduabelah pihak.Pada perkembangan sekarang, secara filopsofis, iddah juga ada yang diberlakukan terhadap laki-laki (suami) dalam kasus-kasus tertentu. Pemberlakuan iddah bagi laki-laki dikenal juga di dalam literature-literatur fiqh seperti, al-Figh al Islami wa Adillatibi.

Ada dua kondisi dimana 'iddah juga sebenarnya diperuntukkan bagi laki-laki. Pertama jika seorang laki-laki mencerai isterinya dengan talak bain, dan laki-laki yang hendak menikahi seorang yang tidak boleh dinikahinya karena perempuan tersebut saudara kandung dengan isteri pertama yang diceraikannya, maka laki-laki itu harus beriddah menunggu hingga 'iddah isteri pertama selesai, yang termasuk ada ikatan mahram dengan calon isteri kedua yang hendak ia nikahi.Kedua, jika seorang laki-laki telah mempunyai empat orang isteri, mentalak salah satunya untuk menikahi yang kelima, maka laki-laki tersebut tidak diperkenankan menikah dengan yang kelima hingga masa 'iddah yang dijalani oleh isteri yang ditalak itu selesai. Wahbah al Zuhaili menambahkan satu kondisi seorang laki-laki tidak boleh langsung menikah pada perempuan yang ditalak olehnya tiga kali, sebelum adanya tahlil atau sebelum ia menikah dengann laki-laki lain, dikenal dengan istilah muballil.

Dengan demikian 'iddah pada hakikatnya dimaksudkan untuk memberikan kesempatan kepada keduabelah pihak suami dan isteri yang bercerai hidup guna merajut kembali ikatan perkawinan yang kandas dan putus karena perceraian, sehingga diberikan peluang untuk mengoreksi kelemahan dan kekurangan masing-masing. Selain itu, untuk menjunjung tinggi nilai-nilai yang terkandung dalam sebuah perkawinan, 


\section{4 ljtimaiyya: Jurnal Pengembangan Masyarakat Islam 10 (1) (2017)}

yaitu dengan menghimpun orang-orang arif mengkaji masalahnya, dan memberi tempo berfikir pada kedua belah pihak. Jika tidak demikian, maka tidak ubahnya seperti anakanak. 'iddah juga mengandung hikmah ibadah kepada Allah (ta'abbudi) dan mematuhi perintahnya yang terkandung di dalam al-Qur'an, dimana perintah itu diperuntukkan bagi perempuan-perempuan muslimah.Yakni ketentuan hukum di dalam nash al-Qur'an dan sunnah yang harus diterima apa adanya dan tidak dapat dinalar secara akal, dimana seorang hamba Allah SWT hanya mengikuti apa yang telah ditetapkan oleh Syảri. Oleh sebab itu hikmah-hikmah ini bersifat bias gender, dan hikmah ini juga dapat ditujukan bagi laki-laki, tidak hanya bagi perempuan saja.

\section{Rekonstruksi Tujuan Pemberlakuan 'iddah}

Konteks sosial yang telah berubah tentu membawa perubahan juga pada tatanan hukum dan tatanan kemasyarakatan. Hadits yang berbunyi الطن ق), dimana aktifitas iddah yang dulunya murni ditujukan bagi isteri/perempuan semata, maka secara kontekstual juga dapat diberlakukan kepada laki-laki dengan pertimbangan moril dan etika, bukan pertimbangan kodrati semata. Sangat tidak adil jika iddah hanya diberlakukan bagi perempuan semata. Konstruksi hukum Islam yang selama ini hanya memberikan ketentuan iddah bagi perempuan, jika dikaitkan dengan konsep moral dan etika, seharusnya juga diberlakukan terhadap laki-laki/suami. Namun tidak berarti meninggalkan nilai-nilai dan tujuan 'iddah itu sendiri.

Etika merupakan aturan atau pola tingkah laku yang dihasilkan oleh akal manusia dan merupakan ilmu pengetahuan yang berhubungan dengan upaya menentukan perbuatan yang dilakukan manusia untuk dikatakan baik dan buruk. Penilaian baik buruk tersebut berdasarkan pendapat akal pikiran secara objektif. Dengan etika seseorang dapat mengemukakan penilaian tentang perilaku manusia. Menjadi 
alat kontrol atau rambu-rambu bagi seseorang dalam melakukan suatu tindakan atau aktivitasnya.

Al-Qur'an melalui sejumlah ayat secara tegas menyatakan bahwa kedudukan antara laki-laki dan perempuan seimbang, ${ }^{14}$ hak dan kewajibannya pun sama di mata hukum dan kemasyarakatan. Islam telah menawarkan konsep kesetaraan dengan memposisikan perempuan dan laki-laki dalam konsep rekanan (partnership) dan keberadaannya diakui sederajat antara hak dan kewajibannya masing-masing termasuk dalam perkawinan dan hal-hal yang menjadi konsekuensi perkawinan. Hal ini ditegaskan dalam al-Qur'an surat al-Ahzab ayat 35 .

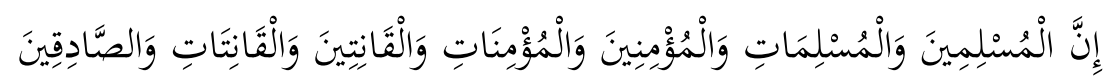

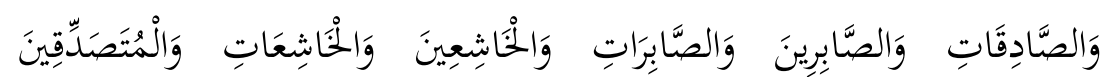

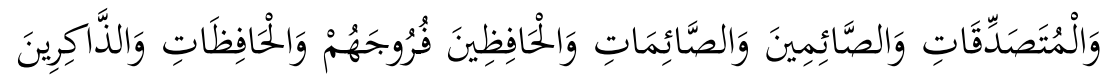

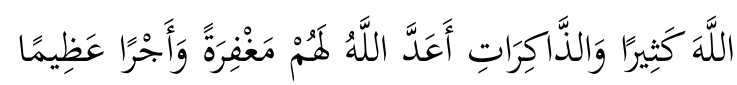

Artinya :

"Sesungguhnya laki-laki dan perempuan yang muslim, lakilaki dan perempuan yang mukmin, laki-laki dan perempuan yang tetap dalam ketaatannya, laki-laki dan perempuan yang benar, laki-laki dan perempuan yang sabar, laki-laki dan perempuan yang khusyuk, laki-laki dan perempuan yang bersedekah, laki-laki dan perempuan yang berpuasa, laki-laki dan perempuan yang memelihara kehormatannya, laki-laki dan perempuan yang banyak menyebut (nama) Allah, Allah telah menyediakan untuk mereka ampunan dan pahala yang besar."

Ayat ini adalah landasan yang kuat adanya kesejajaran dan kemitraan antara laki-laki dan perempuan (antara suami

${ }^{14}$ Nasaruddin Umar, Argumen Kesetaraan Jender Perspektif Al-Qur'an, (Jakarta: Paramadina, 1999), cet. I, h. 247

Pogram Pascasarjana UIN Raden Intan Lampung 
dan isteri). Kemitraan antara laki-laki dan perempuan merupakan konsep hubungan yang meletakkan laki-laki dan perempuan sebagai relasi yang dapat saling mempengaruhi secara positif.

Kemitrasejajaran juga dapat berarti persamaan status mereka dalam masyarakat yang tercermin dalam sikap saling menghargai, menghormati, dan mengisi. Oleh karena itu, lakilaki dan perempuan yang bercerai, sama-sama mempunyai hak dan kewajiban untuk saling menghargai dan menghormati dalam masa 'iddah. Islam telah mewajibkan suami menafkahi isteri yang iddah kecuali jika isteri nusyuz, dan berhak merujuk isterinya selama masa iddah. Isteri mempunyai kewajiban untuk menjaga dirinya di dalam masa iddah, dan berhak menerima nafkah 'iddah.

Iddah dipahami hanya berlaku bagi perempuan namun tidak bagi laki-laki. Hal ini didukung oleh bunyi redaksi ayatayat al-Qur'an dan Hadits Rasulullah Saw. Yang telah dijelaskan sebelumnya. Seorang wanita yang sedang menjalani masa iddah diwajibkan melakukan apa yang disebut dengan mulazamtu al-sakean (ملازمة السكن). Artinya adalah selalu berada di dalam rumah, tidak keluar dari dalam rumah, selama masa 'iddah itu berlangsung. Wanita itu tidak diperkenankan keluar meninggalkan rumah tempat dia dimana menjalani masa 'iddah itu, kecuali ada udzur-uzdur yang secara syar'i memang telah diperbolehkan, atau ada hajat yang tidak mungkin ditinggalkan. Islam menghormati perempuan sebagai manusia yang mempunyai fungsi sebagai ibu bahkan sebagai anggota masyarakat.

Iddah pada prinsipnya diterapkan sebagai wahana untuk mempertimbangkan kembali baik dan buruknya perceraian. Perceraian menimbulkan dampak yang negatif bagi kedua belah pihak, terlebih bagi anak-anak yang lahir dari perkawinan tersebut. Karenanya iddah sesungguhnya merupakan ikatan simbolik adanya kesedihan yang mendalam dipihak suami dan isteri karena runtuhnya ikatan perkawinan yang dipandang sebagai akad yang kokoh (mitsaqanghalidhan). 
Pasangan suami isteri tidak sesuka hatinya memutuskan ikatan perkawinan, kemudian menikah lagi, kemudian bercerai lagi. Pernikahan dijadikan permainan, padahal Rasulullah SAW mencela orang yang gemar kawin cerai berulang-ulang. Rujuk justru merupakan perbuatan yang disukai dan mengandung pahala di sisi Allah Swt. Manakala terjadi perselisihan antara suami dan isteri, maka pihak keluarga kedua belah pihak hendaknya mendatangkan hakam untuk mendamaikan kedua belah pihak. Oleh sebab itu rujuk sebelum habisnya masa iddah tidak memerlukan akad nikah baru.

Interval waktu 'iddah yang ditetapkan oleh syar'i adalah sarana untuk mempertimbangan baik buruknya perceraian (jika perkawinan putus karena perceraian), atau sebagai sarana untuk merenung kembali kelebihan dan kekurangan pasangan masing-masing, karena tidak ada manusia yang sempurna. Kewajiban untuk introspeksi diri tidak hanya dibebankan kepada perempuan/isteri, laki-laki juga memiliki kewajiban yang sama untuk introspeksi diri demi menegakkan etika perceraian.

Dengan demikian hikmah penetapan tentang iddah dalam talak raj'i adalah untuk mendorong kedua belah pihak yang bercerai agar berdamai dan bersatu kembali. Di sisi lain, suami juga hendaknya tidak tergesa-gesa mengambil keputusan untuk menikah sebelum masa 'iddah isteri habis. Jika suami terlalu cepat menikah, kemudian suami isteri ingin rujuk kembali, maka akan terjadi perkawinan poligami, sehingga menimbulkan penyesalan bagi kedua belah pihak. Jadi ada baiknya juga suami bersikap menahan diri untuk tidak menikah hingga habisnya masa iddah isteri, agar masih ada peluang bagi kedua belah pihak untuk kembali membina rumah tangga yang sempat putus.

\section{Relevansi Penerapan 'iddah di Era Teknologi Modern}

Pada prinsipnya syari'at Islam memiliki tujuan untuk mewujudkan kemaslahatan kemanusiaan universal dan 
menolah segala bentuk kemafsadatan. Syari'at Islam dibangun untuk kepentingan manusia dan tujuan universal berupa kemaslahatan, keadilan, rahmatan lil 'alamin dan hikmah kebijaksanaan. Sesungguhnya apa yang diatur dan ditetapkan oleh syari'at Islam sudah sangat baik, hanya saja ada yang sudah diketahui manusia hikmahnya dan ada pula yang belum diketahui sehingga perlu digali dan dikaji.

Perkembangan di bidang ilmu kedokteran dewasa ini semakin maju, terlebih lagi kemajuan sains dan teknologi yang dapat memprediksi kehamilan seorang perempuan. Bahkan dapat memprediksi usia kehamilan (terhitung sejak terjadinya pembuahan pada indung telur), waktu persalinan, jenis kelamin janin, perkembangan janin hingga persalinan, dan lain sebagainya. Dengan menggunakan sarana Ultrasonography (USG), yaitu teknik diagnostik untuk menguji struktur badan bagian dalam yang melibatkan formasi bayangan beberapa dimensi dengan gelombang ultrasonik, maka dengan hitungan detik saja seseorang dapat mengetahui keberadaan janin dalam kandungan. Tidak perlu harus menunggu hingga tiga atau empat bulan sepuluh hari atau tiga kali suci.

"Illat hukum pembersihan rahim tersebut bukanlah satu-satunya alasan pokok diterapkannya aturan tentang iddah bagi perempuan yang bercerai atau ditinggal mati suami. Jika hanya berkaitan dengan 'mengetahui kebersihan rahim, maka persoalan 'iddah dapat diselesaikan dengan kecanggihan teknologi modern sekarang.

Kalangan Syafiiyyah mengemukakan, 15 bahwa iddah dimaksudkan untuk mengetahui kesucian rahim isteri, karena pengabdian kepada Allah SWT (ta'abudi), atau berbela sungkawa atas suami yang meninggal dunia(tafajju).

Pada mulanya iiddah memang dimaksudkan untuk menjaga kesucian garis keturunan, karena perempuan yang beriddah tidak diperbolehkan melangsungkan perkawinan

${ }^{15}$ Abdurrahman al-Jaziri, Al-Figh 'ala Mazabib al-Arba'ah, , (Beirut : Dar al Fikr, 1986), jilid IV, h. 517 
hingga berakhirnya masa iddah. Karena jika tidak ditetapkan aturan tentang 'iddah maka boleh jadi perempuan yang baru beberapa hari pasca berpisah dengan suami pertamanya dalam keadaan hamil itu, menikah lagi dengan laki-laki lain, sehingga nasab anak yang dikandung menjadi tidak jelas.

Namun untuk kondisi saat ini dimana alat tes berupa DNA (Deoxyribo Nucleic Acid) dapat digunakan untuk mendeteksi kebenaran nasab seseorang. Tes DNA merupakan tes yang dilakukan terhadap seseorang sebagai salah satu upaya untuk memperoleh kejelasan identitas yakni sifat keturunan atau genetik dari generasi ke generasi berikutnya. Tintkat akurasi kebenarannya sudah mencapai 99,9 persen, dan dapat dijadikan sebagai penetapan bahwa seseorang memiliki hubungan dengan yang lain.

Dalam kasus-kasus tertentu, kecenderungan yang terjadi dikalangan pasangan suami isteri yang akan bercerai biasanya didahului dengan proses pisah ranjang hingga berbulan-bulan, yang dapat dipastikan mereka tidak melakukan hubungan biologis yang menyebabkan kehamilan. Secara ilmu pengetahuan sudah dapat dipastikan isteri tidak mungkin mengandung jika suaminya tidak pernah menggaulinya, alam kasus seperti ini, iddah masih tetap diberlakukan. Masa iddah dihitung sejak terjadi thalaq diucapkan di persidangan, bukan sejak terjadinya pisah ranjang. ${ }^{16}$

Menurut Wahbah Zuhaili, yang menjalani iddah tersebut adalah perempuan yang bercerai dari suaminya, bukan laki-laki atau suaminya

\footnotetext{
${ }^{16}$ Lihat Pasal 153 ayat 4 Kompilasi Hukum Islam : "Bagi perkawinan yang putus karena perceraian, tenggang waktu tunggu dimulai sejak jatuhnya putusan Pengadilan Agama yang mempunyai kekuatan hukum tetap, sedangkan bagi perkawinan yang putus karena kematian, tenggang waktu tunggu dihitung sejak kematian suami.
} 


$$
\begin{aligned}
& \text { ليس على الرجل عدة بالمعنى الاصطالحي، فيجوز له بعد الفرقة مباشرة أن } \\
& \text { يتزوج بزوجة أخرى، مالم يوجد مانع شرعي، كالتزوج بمن لايحل له الجمع بين } \\
& \text { زوجته الأولى وبين قريباتها المحارم كالأخت } 17
\end{aligned}
$$

(Tidak ada bagi laki untuk ber-iddah menurut definisi istilahi, sehingga boleh baginya langsung menikah dengan wanita lain setelah berpisah selagi tidak ada sesuatu yang menghalanginya menurut syara', seperti : menikahi wanita yang tidak halal baginya dengan mengumpulkan antara istrinya yang pertama dengan kerabat dekatnya yang haram ia nikahi seperti saudara perempuannya).

Dengan demikian, dalam kasus-kasus yang tidak secara tegas dikemukakan oleh al-Qur'an atau Sunnah, penetapan 'iddah merupakan ijtihad para ulama', seperti wacana pemberlakuan iddah bagi laki-laki, dapat ditetapkan dengan ijtihad ulama manakala akan mendatangkan manfaat dan menghilangkan kemudharatan, khususnya perceraian yang terjadi karena talak raj'i. Namun hal penting yang perlu dipertimbangkan adalah manusia memilliki logika berfikir yang sangat terbatas, sebab apa yang dipandang baik oleh akall belum tentu baik menurut al-Qur'an dan Sunnah. Penentu dan penetap kemaslahatan hanya Allah dan Rasulnya.

\section{Kesimpulan}

Terdapat beberapa hal yang perlu dipertimbangkan untuk dijadikan alasan penerapan 'iddah di era modern saat ini. Jika 'illat hukum yang dijadikan sebab pemberlakuan iddah karena untuk mengetahui kosongnya rahim dari janin, maka konsekuensinya 'iddah tidak lagi relevan untuk diberlakukan, dikarenakan teknologi USG (Ultrasonography)dan DNA (Deoxyribo Nucleic Acid) yang semakin canggih telah dapat

${ }^{17}$ Wahbah al-Zuhaili, Al-Fighu al-Islamy wa Adillatubu, (Suriah: Dar al Fikr bi Damsyiq, 2002), Juz 10, h. 626 
mendeteksi secara dini kondisi rahim seseorang dan nashab dari janin yang dikandung oleh seorang perempuan.

Perkembangan ilmu pengetahuan dan teknologi saat ini bukan alasan untuk menghapus ketetapan tentang 'iddah yang telah diatur dalam al-Qur'an maupun Sunnah sebagai sumber hukum Islam. Pelembagaan iddah masih relevan untuk ditaati sebagai bukti keimanan semua pihak terhadap nilai-nilai luhur yang terkandung di dalam al-Qur'an maupun Hadits. Secara eksplisit, eksistensi 'iddah sangat penting dalam menjaga kehormatan dan kredibilitas baik pihak perempuan maupun laki-laki. Laki-laki dan perempuan yang putus perkawinan karena kematian maupun cerai hidup harus menghargai hakikat perkawinan. Bahwa perkawinan pada hakikatnya adalah ikatan yang kuat dan kokoh, bukan dijadikan sebagai boneka permainan.

Ajaran Islam tidak membeda-bedakan hak antara lakilaki dan perempuan, bahwa nilai-nilai fundamental yang mendasari ajaran Islam seperti perdamaian, pembebasan dan legaliterianisme termasuk persamaan derajat antara laki-laki dan perempuan banyak tercermin dalam ayat al-Qur'an, kisah-kisah tentang peranan penting kaum perempuan di zaman Nabi Muhammad Saw. Prinsip dasar ajaran Islam ini akan tetap membumi hingga akhir zaman meskipun kecanggihan ilmu pengetahuan dan teknologi yang terus berkembang.

Aturan Hukum Islam tidak akan pernah tandus dan kering dari spirit ruhaniyah dalam merespom perkebangan ilmu pengetahuan dan teknologi modern. Yang terpenting adalah ikhtiar dalam memikirkan konstruksi dan rekonstruksi fiqh baru yang lebih komitmen terhadap nilai-nillai moralitas kolektif, demokratif dan aplikatif. 


\section{Daftar Pustaka}

Abdurrahman al-Jaziri, Al-Fiqh 'ala Mazabib al-Arba'ah, jilid IV, Beirut : Dar al-Fikr, 1986

Abu Yahya Zakariyya al-Ansari, Fath al-Wabhab bi-Syarh

Minhaj at-Tullab,Juz III,Semarang: Toha Putra, T'T

Amir Syarifuddin, Hukum Perkawinan Islam di Indonesia, Antara

Fiqh Munaahat dan Undang-Undang Perkasinan, Jakarta :

Kencana, 2007

http:/ / fidianurulmaulidah.wordpress.com

http://www.perkuliahan.com

https://almahaj.or.id.

Ibnu Katsir, Tafsir Ibnu Katsir, Cetakan III, Darut Thayibah, Maktabah Syamilah 8/144

Ibnu Rusyd, Bidayah al-Mujtahid

Imam Abdullah Muhammad bin Ismail al-Bukhari, Sabib

Bukhari, jilid VII, terj. Ahmad Sunarto dkk., Semarang:

CV. Asy-Syifa', 1993

Imam Taiqyy Al-Din Abi bakar, Kifayah al-Akbyar, Beirut,

Lebanon: Dar al-Kutub al-Ilmiyyah, 2005

Kompilasi Hukum Islam

Nasaruddin Umar, Argumen Kesetaraan Jender Perspektif Al-

Qur'an, cet. I, Jakarta: Paramadina, 1999

Syaikh Muhamad Kamil Uwaidah, Al Jami' fi Fiqh An-Nisa'

(Fiqh Wanita : Penerjemah M. Abdul Ghofar, E.M), Jakarta : Pustaka al-Kautsar, cet. I, 1998

Wahbah al-Zuhaili, Al-Fiqhu al-Islamy wa Adillatubu, Suriah:

Dar al-fikr bi Damsyiq, Juz 10, 2002 